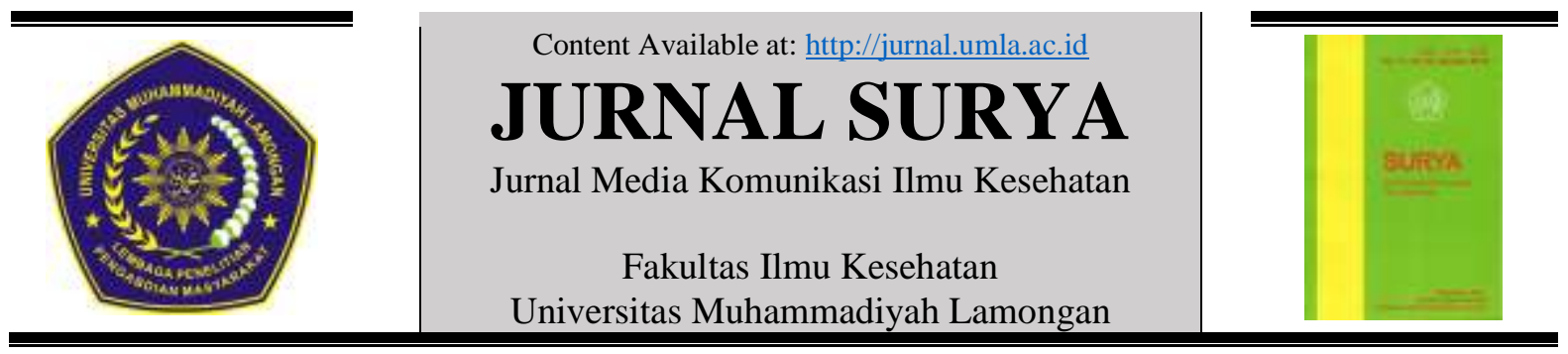

\title{
Pengaruh Penyuluhan Berbasis Video Whatsapp tentang Persalinan Terhadap Pengetahuan dan Sikap Ibu Hamil Trimester III di Puskesmas Klabang Kabupaten Bondowoso
}

Kholisotin, Yuana Dwi Agustin, Agung Dwi Prasetyo

Universitas Nurul Jadid

\section{ARTIKEL INFO}

\section{Article History:}

\section{Kata Kunci:}

Penyuluhan Persalinan

Video Penyuluhan

Persalinan

\begin{abstract}
ABSTRAK
Background: Pertolongan persalinan merupakan faktor penting dalam upaya menurunkan angka kematian ibu dan anak. Di Indonesia pemanfaatan pertolongan persalinan oleh tenaga kesehatan yang kompeten masih kurang dibandingkan target yang diharapkan, termasuk di Kecamatan Klabang Kabupaten Bondowoso pada tahun 2018 hanya mencapai $86,10 \%$.

Objectives: Penelitian ini bertujuan untuk menganalisis pengaruh penyuluhan berbasis video whatsapp tentang persalinan terhadap pengetahuan dan sikap ibu hamil trimester III di Puskesmas Klabang Kabupaten Bondowoso. Design: Penelitian ini menggunakan desain One Group Pretest-Posttest. Populasi penelitian ini adalah semua ibu hamil Trimester III di wilayah kerja Puskesmas Klabang yang diperkirakan melahirkan pada bulan Mei-Juni tahun 2019, dengan jumlah sampel sebesar 33 orang. Analisis data menggunakan uji Wilcoxon dengan nilai signifikansi sebelum dan setelah penyuluhan sebesar $0,000<0,005$.

Results: dari 33 responden, 20 responden menunjukkan adanya peningkatan sikap yang positif setelah diberikan eksperimen. Hasil analisa statistik dengan uji Wilcoxon diperoleh nilai $p$ - value $0,000(\mathrm{p}<0,05)$, artinya terdapat pengaruhartinya terdapat perbedaan sikap sebelum dan sesudah dilakukan penyuluhan berbasis video whatsapp tentang persalinan. Sehingga $\mathrm{H}_{0}$ ditolak yang berarti bahwa ada perbedaan atau hipotesa peneliti diterima.
\end{abstract}

Conclusions: Disimpulkan bahwa ada pengaruh penyuluhan berbasis video whatsapp tentang persalinan terhadap pengetahuan dan sikap ibu hamil trimester III di Puskesmas Klabang Kabupaten Bondowoso.

Korespondensi Penulis: ns.lilis87@gmail.com yuanadwi1975@gmail.com

yayoagung@gmail.com 


\section{PENDAHULUAN}

Pertolongan persalinan merupakan faktor penting dalam upaya menurunkan angka kematian ibu dan anak. Pertolongan persalinan oleh tenaga kesehatan adalah pelayanan persalinan yang aman yang dilakukan oleh tenaga kesehatan yang kompeten. Pada kenyataan di lapangan masih terdapat penolong persalinan yang bukan tenaga kesehatan dan dilakukan diluar fasilitas pelayanan kesehatan. Tenaga kesehatan yang berkompeten memberikan pelayanan pertolongan persalinan adalah dokter spesialis kebidanan, dokter dan bidan.

Pertolongan persalinan oleh tenaga kesehatan merupakan strategi untuk menangani masalah kesehatan ibu dan anak di Indonesia. Kemampuan dan keterampilan penolong persalinan sangat mempengaruhi terjadinya kematian ibu maupun bayi. Menurut hasil penelitian dari 97 negara bahwa ada korelasi yang signifikan antara pertolongan persalinan dengan kematian ibu. Semakin tinggi cakupan persalinan oleh tenaga kesehatan di suatu wilayah akan diikuti penurunan kematian ibu di wilayah tersebut.

Dalam sebuah hadits Rasulullah Muhammad SAW sudah memberikan panduan kepada kita bahwa setiap urusan atau tugas harus diberikan dan dilaksanakan oleh orang yang berkompeten di bidangnya.

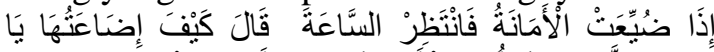

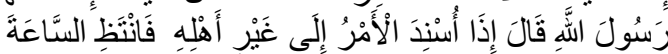
Rasulullah shallallahu 'alaihi wasallam bersabda: Jika amanat telah disia-siakan, tunggu saja kehancuran terjadi. Ada seorang sahabat bertanya; bagaimana maksud amanat disia-siakan? Nabi menjawab; Jika urusan diserahkan bukan kepada ahlinya, maka tunggulah kehancuran itu.

Dalam kaitannya dengan permasalahan ini, bahwa pertolongan persalinan yang dilakukan oleh tenaga non kesehatan (dukun) akan sangat beresiko dan berbahaya.

Hasil Riskesdas tahun 2017 menunjukkan bahwa penolong persalinan dengan kualifikasi tertinggi di Indonesia dilakukan oleh bidan $(68,6 \%)$, oleh dokter $(18,5 \%)$, dan oleh non tenaga kesehatan $(11,8 \%)$. Sementara itu cakupan persalinan oleh tenaga kesehatan di Provinsi Jawa Timur pada tahun 2017 masih sangat memprihatinkan, karena hanya 7 (tujuh) kabupaten/kota yang mencapai target, yaitu Kabupaten Lamongan, Kabupaten Lumajang, Kabupaten Bangkalan, Kabupaten Trenggalek, Kabupaten Bojonegoro, Kabupaten Sampang dan Kota Madiun. Hasil cakupan persalinan oleh tenaga kesehatan untuk Provinsi Jawa Timur pada tahun 2017 adalah $89,14 \%$. Angka ini di bawah target yang telah ditentukan, yakni $94 \%$.

Di Kabupaten Bondowoso, cakupan pertolongan persalinan oleh tenaga kesehatan pada tahun 2017 hanya mencapai 90,8\% dari target yang ditetapkan adalah $95 \%$, sementara itu sampai dengan bulan Desember tahun 2018 ini masih mencapai 90,47\% dari target yang di tetapkan sebesar 95\%. Puskesmas Klabang merupakan puskesmas dengan cakupan persalinan oleh tenaga kesehatan terendah di Kabupaten Bondowoso.

Data dari Dinas Kesehatan Kabupaten Bondowoso menunjukkan angka cakupan persalinan tenaga kesehatan Puskesmas Klabang pada tahun 2017 adalah 76,06\%, dan sampai dengan bulan Desember tahun 2018 mencapai $86,10 \%$. dari target yang ditetapkan 95\%. Seiring dengan hal itu pertolongan persalinan di dukun dalam tiga tahun terakhir juga masih cukup tinggi. Pada tahun 2017 mencapai 14 kasus $(8,2 \%)$, tahun 2017 ada 14 kasus (9,7\%), dan sampai dengan bulan Desember tahun 2018 sudah mencapai 16 kasus $(17,1 \%)$. Dukun bersalin yang ada di wilayah Kecamatan Klabang saat ini berjumlah 20 orang, dan 10 orang yang sudah bermitra dengan petugas kesehatan.

Secara teori keputusan pemilihan penolong persalinan oleh ibu hamil bisa dipengaruhi oleh beberapa faktor. Lawrence Green menyatakan bahwa perilaku kesehatan seseorang dipengaruhi oleh tiga faktor determinan, yaitu faktor predisposisi (predisposing factors), faktor pemungkin atau pendukung (enabling factors), dan factor penguat (reinforcing factors). Faktor predisposisi meliputi pendidikan, pengetahuan, sikap, kepercayaan, tradisi, norma sosial, dan pengalaman. Faktor pemungkin diantaranya adalah ketersediaan sumberdaya, biaya, fasilitas kesehatan, keterjangkauan fasilitas kesehatan. Sementara yang termasuk dalam faktor pendorong antara 
lain dukungan keluarga, suami, teman, sikap dan perilaku petugas kesehatan.

Penyebaran informasi merupakan hal yang harus diperhatikan agar informasi lebih maksimal dan tujuannya dapat tercapai serta dapat merubah sikap atau perilaku seseorang menjadi lebih baik. Keterbatasan ruang komunikasi menjadikan penyebaran informasi menjadi tidak efektif dan sering terjadi miss communication. Namun, saat ini banyak teknologi komunikasi yang dirancang untuk memudahkan penyebaran informasi. Salah satu produk teknologi yang diminati masyarakat adalah internet. Berdasarkan survey yang dilakukan oleh Asosiasi Penyelenggara Jasa Internet Indonesia (APJII), diperoleh informasi bahwa jumlah pengguna internet di Indonesia mencapai 132,7 juta orang pada tahun 2016 dan 97,4 persen dari pengguna internet di Indonesia menggunakan media sosial. Untuk kategori komunikasi, aplikasi media sosial paling populer yang ada di posisi pertama adalah WhatsApp Messenger, yang sudah didownload oleh 1 Miliar orang.2 Posisi kedua adalah Facebook Lite dengan jumlah downloader sebanyak 500 Juta.3 Posisi selanjutnya sebagai aplikasi komunikasi paling populer di Indonesia adalah Messenger, Shareit, Tik Tok, Instagram, dan masih banyak yang lainnya.

Penggunaan video sebagai sarana penyuluhan kesehatan kini mulai dikembangkan seiring dengan kemajuan teknologi saat ini. Penyuluhan kesehatan melalui media video memiliki kelebihan dalam hal memberikan visualisasi yang baik sehingga memudahkan proses penyerapan pengetahuan.Video termasuk dalam media audio visual karena melibatkan indera pendengaran sekaligus indera penglihatan. Media audio visual ini mampu membuahkan hasil belajar yang lebih baik untuk tugastugas seperti mengingat, mengenali mengingat kembali dan menghubunghubungkan fakta dan konsep.

Penelitian ini fokus pada pemanfaatan media sosial WhatsApp, karena WhatsApp adalah media sosial yang paling populer oleh masyarakat. WhatsApp merupakan sebuah aplikasi media sosial yang dirancang untuk memudahkan penggunanya dalam berkomunikasi melalui berbagai macam fitur yang tersedia. Beberapa fitur yang ada pada aplikasi WhatsApp antara lain Chat Group, WhatsApp di Web dan Desktop, Panggilan Suara dan Video WhatsApp, Enskripsi EndTo-End, Pengiriman Foto dan Video, Pesan Suara, dan Dokumen. Media sosial WhatsApp melalui bereagam fitur yang disediakan dapat digunakan untuk kegiatan yang lebih bermanfaat, misalnya untuk pendidikan.

Beberapa penelitian telah menjelaskan tentang dampak positif video dalam peningkatan kognitif individu tentang kesehatan. Video merupakan media yang paling sering digunakan oleh promotor kesehatan sebagai media yang memfasilitasi pengembangan aspek kognitif hingga keterampilan individu dan lingkup komunitas. Penggunaan ponsel yang massive merupakan peluang yang dimanfaatkan oleh promotor kesehatan sebagai media edukasi informasi kesehatan. Pengiriman video melalui ponsel lebih efektif dan cost effective dibandingkan dengan kegiatan penyuluhan. Pengiriman video ke ponsel dapat dilakukan dalam satu waktu dan mencakup segmentasi kemasyarakat secara luas dalam satu waktu. Penggunaan video informasi kesehatan merupakan aspek potensial pada penerima pesan dengan tingkat literasi rendah. Penyampaian informasi melalui video meningkatkan minat belajar dan mudah diterima oleh penerima pesan.

Berdasarkan permasalahan tersebut, peneliti tertarik ingin mengetahui Pengaruh Penyuluhan Berbasis Video Whatsapp Tentang Resiko Persalinan Terhadap Pengetahuan Dan Sikap Ibu Hamil Trimester III di wilayah kerja Puskesmas Klabang Kabupaten Bondowoso pada tahun 2019.

\section{METODE PENELITIAN}

Penelitian ini menggunakan metode penelitian korelasional dengan desain penelitian menggunakan One Group Pra-Post test Design dengan jumlah sampel 33 responden yang memenuhi kreteria inklusi dengan teknik total sampling. Analisis data yang digunakan dalam penelitian ini adalah analisis univariat, analisis bivariat dengan uji statistik Wilcoxone 
HASIL PENELITIAN

1. Data Umum

Tabel 1 Karakteristik Responden

\begin{tabular}{|c|c|c|c|}
\hline No & Data Umum & $\mathbf{F}$ & $\%$ \\
\hline \multicolumn{4}{|c|}{ Usia } \\
\hline 1 & $20-25$ tahun & 11 & 33,3 \\
\hline 2 & $25-30$ tahun & 15 & 45,5 \\
\hline 3 & $30-35$ tahun & 7 & 21,2 \\
\hline \multicolumn{4}{|c|}{ Pendidikan } \\
\hline 1 & $\mathrm{SD}$ & 7 & 21,2 \\
\hline 2 & SMP & 9 & 27,3 \\
\hline 3 & SMA & 11 & 33,3 \\
\hline 4 & Akademi/Sarjana & 6 & 18,2 \\
\hline \multicolumn{4}{|c|}{ Pekerjaan } \\
\hline 1 & Ibu Rumah Tangga & 14 & 42,4 \\
\hline 2 & Wiraswasta & 13 & 39,4 \\
\hline 3 & PNS & 5 & 15,2 \\
\hline 4 & Lainnya & 1 & 1 \\
\hline \multicolumn{4}{|c|}{ Paritas } \\
\hline 1 & Pertama & 10 & 30,3 \\
\hline 2 & Kedua & 16 & 48,5 \\
\hline 3 & Ketiga & 6 & 18,2 \\
\hline 4 & Keempat & 1 & 3,0 \\
\hline \multicolumn{2}{|c|}{ Total } & 33 & 100 \\
\hline \multicolumn{4}{|c|}{$\begin{array}{l}\text { Pada tabel } 1 \text { diperoleh bahwa } \\
\text { responden paling banyak berusia } 25-30 \text { tahun } \\
\text { sebesar } 45,5 \% \text {, berpendidikan SMA/sederajat } \\
\text { sebesar } 33,3 \% \text {, bekerja sebagai ibu rumah } \\
\text { tangga sebesar } 42,4 \% \text {, paritas kedua sebesar } \\
48,5 \% \text {. }\end{array}$} \\
\hline
\end{tabular}

\section{Data Khusus}

Tabel 2 Distribusi Tingkat Pengetahuan Sebelum Diberikan Video Penyuluhan Persalinan

\begin{tabular}{lcc}
\hline Pengetahuan Ibu & \multicolumn{2}{c}{ Pre Eksperimen } \\
\cline { 2 - 3 } Hamil Trimester III & F & \% \\
\hline Pengetahuan Kurang & 11 & 33.3 \\
Pengetahuan Cukup & 19 & 57.6 \\
Pengetahuan Baik & 3 & 9.1 \\
\hline
\end{tabular}

Pada tabel 2 diperoleh bahwa paling banyak responden memiliki pengetahuan yang cukup sebanyak 57,6\% (19 responden).

Tabel 3 Distribusi Tingkat Pengetahuan Setelah Diberikan Video Penyuluhan Persalinan

\begin{tabular}{lcc}
\hline Pengetahuan Ibu & \multicolumn{2}{c}{ Post Eksperimen } \\
\cline { 2 - 3 } Hamil Trimester III & F & \% \\
\hline Pengetahuan Kurang & 3 & 9.1 \\
Pengetahuan Cukup & 9 & 27.3 \\
Pengetahuan Baik & 21 & 63.6 \\
\hline
\end{tabular}

Pada tabel 3 diperoleh bahwa paling banyak responden memiliki pengetahuan yang baik sebanyak 63,3\% (21 responden).

Tabel 4 Distribusi Sikap Sebelum Diberikan Video Penyuluhan Persalinan

\begin{tabular}{|c|c|c|c|}
\hline \multirow{2}{*}{$\begin{array}{l}\text { Sikap Ibu } \\
\text { Trimester III }\end{array}$} & \multirow[t]{2}{*}{ Hamil } & \multicolumn{2}{|c|}{ Post Eksperimen } \\
\hline & & $\mathbf{F}$ & $\%$ \\
\hline Negatif & & 28 & 84.8 \\
\hline Positif & & 5 & 15.2 \\
\hline
\end{tabular}

Tabel 5 Distribusi Sikap Setelah Diberikan Video Penyuluhan Persalinan

\begin{tabular}{|c|c|c|c|}
\hline \multirow{2}{*}{$\begin{array}{l}\text { Sikap Ibu } \\
\text { Trimester III }\end{array}$} & \multirow[t]{2}{*}{ Hamil } & \multicolumn{2}{|c|}{ Post Eksperimen } \\
\hline & & $\mathbf{F}$ & $\%$ \\
\hline Negatif & & 9 & 27.3 \\
\hline Positif & & 24 & 72.7 \\
\hline
\end{tabular}
banyak responden memiliki sikap yang positif sebanyak $72,7 \%$ ( 24 responden).

Tabel 6 Perbedaan Tingkat Pengetahuan Sebelum dan Setelah Diberikan Video Penyuluhan Persalinan

\begin{tabular}{|c|c|c|c|c|c|c|c|}
\hline \multirow{2}{*}{$\begin{array}{l}\text { Perubahan } \\
\text { pengetahu } \\
\text { an }\end{array}$} & \multicolumn{6}{|c|}{ Pengetahuan } & \multirow{3}{*}{$\begin{array}{l}\text { Asymp } \\
\text { Sig. (2. } \\
\text { tailed) }\end{array}$} \\
\hline & $\begin{array}{l}\text { Menin } \\
\text { gkat }\end{array}$ & & $\begin{array}{l}\text { Menur } \\
\text { un }\end{array}$ & & $\begin{array}{l}\text { Teta } \\
p\end{array}$ & & \\
\hline sebelum & $\mathrm{F}$ & $\%$ & $\mathrm{~F}$ & $\%$ & $\mathrm{~F}$ & $\%$ & \\
\hline $\begin{array}{l}\text { dan } \\
\text { setelah }\end{array}$ & 23 & 69,7 & 1 & 3,0 & 9 & 27,3 & 0,000 \\
\hline
\end{tabular}
responden menunjukkan adanya peningkatan pengetahuan setelah dilakukan eksperimen. Hasil analisa statistik dengan uji Wilcoxon diperoleh nilai $p$ - value $0,000 \quad(\mathrm{p}<0,05)$, artinya terdapat perbedaan pengetahuan sebelum dan sesudah dilakukan penyuluhan berbasis video whatsapp tentang persalinan. Sehingga $\mathrm{H}_{0}$ ditolak yang berarti bahwa ada perbedaan atau hipotesa peneliti diterima.

Tabel $7 \quad$ Perbedaan $\quad$ Sikap Sebelum dan Setelah Diberikan Video Penyuluhan Persalinan

\begin{tabular}{|c|c|c|c|c|c|c|c|}
\hline \multirow{4}{*}{$\begin{array}{l}\text { Sikap } \\
\text { sebelum } \\
\text { dan } \\
\text { setelah }\end{array}$} & \multicolumn{6}{|c|}{ Sikap } & \multirow{3}{*}{$\begin{array}{l}\text { Asymp } \\
\text { Sig.(2- } \\
\text { tailed) }\end{array}$} \\
\hline & \multirow{2}{*}{$\begin{array}{c}\begin{array}{c}\text { Meni- } \\
\text { ngkat }\end{array} \\
\text { F }\end{array}$} & \multicolumn{2}{|r|}{$\begin{array}{l}\text { Menu- } \\
\text { run }\end{array}$} & \multicolumn{3}{|c|}{$\begin{array}{l}\text { Tet- } \\
\text { ap }\end{array}$} & \\
\hline & & $\%$ & $\mathrm{~F}$ & $\%$ & $\mathrm{~F}$ & $\%$ & \\
\hline & 20 & 60,6 & 1 & 3.0 & 12 & 36,4 & 0,000 \\
\hline
\end{tabular}
responden menunjukkan adanya peningkatan 
sikap yang positif setelah diberikan eksperimen. Hasil analisa statistik dengan uji Wilcoxon diperoleh nilai $p$ - value 0,000 $(\mathrm{p}<0,05)$, artinya terdapat pengaruhartinya terdapat perbedaan sikap sebelum dan sesudah dilakukan penyuluhan berbasis video whatsapp tentang persalinan. Sehingga $\mathrm{H}_{0}$ ditolak yang berarti bahwa ada perbedaan atau hipotesa peneliti diterima.

\section{PEMBAHASAN}

\section{Interpretasi Hasil dan Diskusi Hasil}

1) Umur

Berdasarkan data umur responden ini, menurut peneliti bahwa umur 25 - 30 tahun merupakan usia yang masih dalam rentang aman untuk melahirkan dan ibu masih memiliki pola pikir atau daya tangkap yang baik ketika menerima sesuatu, serta dapat berfikir lebih rasional.

Hal ini sejalan dengan teori Bakri yang menyatakan bahwa jumlah wanita usia subur yang paling banyak pada rentang usia 20-35 tahun yaitu 28 responden (63.6\%). Usia mempunyai pengaruh terhadap daya tangkap dan pola pikir seseorang. Selain itu, usia mungkin dapat berpengaruh terhadap kondisi panca indera dan ingatan responden, disamping faktor lain seperti keberagaman karakteristik seseorang. Semakin bertambah usia maka semakin berkembang pola daya tangkap dan pola pikirnya, sehingga tingkat pengetahuan akan meningkat.

2) Pendidikan

Menurut peneliti pendidikan seseorang menentukan kemampuan berfikir, semakin tinggi pendidikan seseorang maka kemampuan berfikir lebih tinggi dari yang mempunyai pendidikan lebih rendah dan kemudahan dalam menerima informasi yang disampaiakan.

Hal ini sejalan dengan teori Budiman yang menyatakan bahwa pendidikan mempengaruhi proses belajar, makin tinggi pendidikan seeorang makin mudah orang tersebut untuk menerima informasi. Dengan pendidikan tinggi maka seseorang akan cenderung untuk mendapatkan informasi, baik dari orang lain maupun dari media massa. Semakin banyak informasi yang masuk semakin banyak pula pengetahuan yang didapat tentang kesehatan.
3) Pekerjaan

Menurut peneliti, pekerjaan seseorang akan mempengaruhi kehidupan seseorang dan banyaknya informasi yang didapkan. Ibu yang bekerja akan memiliki banyak informasi dan pengalaman, sedangkan ibu yang hanya sebagai ibu rumah tangga akan terbatas dalam sumber informasi yang didapat dan cenderung lebih aktif ibu yang bekerja.

Perempuan yang bekerja memiliki kemampuan untuk mengenali masalah kesehatan keluarga. Pengetahuan perempuan bekerja tentang masalah kesehatan didapatkan dari buku, majalah, koran, radio dan televisi. Perempuan yang bekerja memiliki kemampuan mengambil keputusan untuk mengatasi masalah kesehatan yang dihadapi. Oleh karena itu wanita yang berperan sebagai pekerja sekaligus sebagai seorang istri dan ibu rumah tangga umumnya memiliki kesehatan yang lebih baik dan mempunyai status ekonomi yang lebih baik.

4) Paritas

Menurut peneliti bahwa paritas ibu akan mempengaruhi pengalaman seseorang dalam melahirkan. Ibu yang sudah pernah melahirkan akan lebih memiliki pengalaman dan pengetahuan tentang bagaiamana proses persalinan daripada ibu yang belum pernah melahirkan. Sehingga membutuhkan informasi untuk persiapan dalam proses persalinan.

Paritas seorang wanita dapat mempengaruhi kesehatan psikologis ibu hamil, terutama pada ibu hamil trimester III yang akan menghadapi proses pesalinan. Pada ibu hamil dengan paritas primigravida masih belum memiliki bayangan mengenai apa yang terjadi saat bersalin dan sering dijumpai merasa ketakutan karena sering mendengarkan cerita mengenai apa yang akan terjadi saat usia kehamilan semakin bertambah mendekati waktu persalinan dengan terbayang proses persalinan yang menakutkan (Mezy, 2016), sedangkan ibu hamil dengan paritas multigravida mayoritas sudah memiliki gambaran mengenai kehamilan dan proses persalinan dari kehamilan sebelumnya. Sehingga saat hamil cenderung lebih mempersiapkan mental dan psikologi. 
5) Tingkat Pengetahuan ibu hamil trimester III tentang persalinan sebelum diberikan video penyuluhan persalinan

Menurut peneliti pengetahuan yang cukup ini dipengaruhi oleh tingkat pendidikan yang sebagian besar SMA, dan bekerja sebagai ibu rumah tangga.Sehingga informasi yang diperoleh tentang persalinan belum begitu banyak dan membutuhkan adanya informasi yang diberikan kepada ibu hamil trimester III menjelang persalinan.

Tingkat pengetahuan ibu hamil yang masih rendah. Dipengaruhi oleh kebanyakan responden tidak mengerti secara konkrit pengertian, tujuan dan manfaat melakukan pemeriksaan kehamilan dengan adanya penyuluhan kesehatan mereka dapat memahami dan menambah pengetahuan dan wawasannya bagaimana cara untuk menjaga dan mengasuh kehamilan ibu hamil. Kecenderungan seseorang yang berpengetahuan tinggi akan cenderung mempunyai perilaku yang baik dalam bidang kesehatan dalam hal ini untuk melakukan pemeriksaan kehamilan oleh ibu hamil.

6) Tingkat Pengetahuan ibu hamil trimester III setelah diberikan video penyuluhan persalinan

Analisa hasil kuisioner menunjukkan bahwa adanya pemahaman yang sudah meningkat tentang pengertian kehamilan, proses persalinan dan pengertian abortus. Akan tetapi terdapat jumlah nilai pengetahun yang masih rendah tentang keyakinan untuk mencegah terjadinya penyakit selama persalinan, masih adanya yang menjawab ritual-ritual adat istiadat dan masih adanya persepsi Melakukan pemeriksaan jika sudah hampir melahirkan. Peneliti maupun petugas kesehatan selalu memberikan penyuluhan maupun sosialisasi tentang kehamilan pada ibu hamil agar mereka menghindari kebiasaan lama (faktor budaya) untuk memilih melakukan pemeriksaan dukun bayi dibandingkan melakukan pemeriksaan di fasilitas kesehatan yang memiliki perlengkapan memadai selama proses kehamilan sampai persalinan.

Penyuluhan dilakukan dengan media video. Pesan yang disajikan video dapat berupa fakta (kejadian/peristiwa penting, berita) maupun fiktif (misal cerita) dapat pula bersifat informatif, edukatif, maupun intruksional. Video dapat menggambarkan suatu objek yang bergerak bersama-sama dengan suara alamiah atau suara yang sesuai. Video dapat menyajikan informasi, memaparkan proses, menjelaskan konsepkonsep yang rumit, dan mempengaruhi sikap.

7) Sikap ibu hamil trimester III sebelum diberikan video penyuluhan persalinan

Analisa hasil kuisioner penelitian didapatkan bahwa responden masih memiliki sikap yang negative tentang Perdarahan yang banyak pada saat persalinan merupakan hal yang biasa, Salah satu prinsip pertolongan persalinan adalah harus memperhatikan pencegahan infeksi, Jika selama kehamilan tidak terjadi masalah / resiko maka persalinan boleh ditolong oleh dukun, Pertolongan persalinan oleh dukun sangat berisiko oleh karena dukun tidak mengetahui mekanisme atau proses persalinan. Sehingga perlunya peneliti dalam menekankan hal ini.

Faktor-fakor yang mempengaruhi sikap seseorang adalah, pengalaman pribadi, pengaruh orang yang dianggap penting, kebudayaan, media massa, lembaga pendidikan, faktor emosional. Pembentukan sikap tidak hanya dipengaruhi oleh pengalaman yang dialami seseorang, tetapi informasi yang diberikan oleh oranglain juga akan ikut mempengaruhi. Faktor predisposisi yang salah satunya adalah faktor pengetahuan. Kurang nya ibu memperhatikan kesehatannya dan kehamilannya dikarenakan ibu sibuk memikirkan anak dan rumah tangganya serta kurangnya informasi yang didapatkan oleh ibu mengenai P4K (Persainan dan Pencegahan Komplikasi) juga mempengaruhi sikap ibu tentang upaya pencegahan komplikasi pada ibu hamil.

8) Sikap ibu hamil trimester III setelah diberikan video penyuluhan persalinan

Hasil analisa kuisioner didapatkan bahawa adanya pengingkatan sikap responden terkait poin tidak adanya responden yang mempunyai sikap: selama kehamilan tidak terjadi masalah / resiko maka persalinan boleh ditolong oleh dukun, dan pertolongan persalinan oleh dukun sangat berisiko oleh karena dukun tidak mengetahui mekanisme atau proses persalinan. Semua responden sudah memiliki sikap yang baik untuk kedua poin tersebut. Akan tetapi, terdapat hasil kuisioner sikap yang masih belum baik yaitu: gerakan janin tidak terasa (tidak bergerak) dalam satu hari, ini merupakan tanda bahaya 
dalam kehamilan dan harus segera periksa ke bidan / dokter dianggap meruapakan suatu hal yang wajar. Dan point sikap yang kurang adalah Perdarahan yang banyak pada saat persalinan merupakan hal yang biasa, responden menggap bahwa perdarahan saat persalinan adalah wajar karena pasti saat persalinan banyak mengeluarkan darah.

Hasil penelitian ini sejalan dengan penelitian yang dilakukan oleh Kholisotin (2017) yang berjudul 'Efektifitas paket edukasi preeklampsia terhadap pengetahuan, sikap, dan keterampilan ibu hamil yang beresiko mengalami preeklampsia di kabupaten situbondo', menunjukan adanya peningkatan sikap sebelum dan setelah diberikan penyuluhan. Semakin matang usia seseorang akan mempengaruhi pengalamannya, baik dalam memperoleh pengetahaun dan menentukan sikap, informasi. Berdasarkan pengalaman seseorang dapat saling bertukar pikiran atau sharing, sehingga dapat meningkatkan pengetahuan.

9) Perbedaan tingkat pengetahuan ibu hamil trimester III sebelum dan setelah diberikan video penyuluhan persalinan

Menurut peneliti media penyuluhan berperan penting terhadap peningkatan pengetahuan dan sumber informasi. Dengan adanya modifikasi media penyuluhan maka akan semakin meningkatkkan tingkat pengetahuan dan dapat menurunkan angka kesakitan yang ada atau dapat menurunkan angka kematian bayi yang masih tinggi. Video berbasis whatsapp ini merupakan terobosan dan inovasi baru di bidang penyuluhan kesehtan berbasis elektronik untuk mengikuti perkembangan zaman yang ada saat ini.

Penyuluhan melibatkan adanya aktivitas mendengar, berbicara dan melihat yang membuat metode ini efektif. Menganalisa bahwa informasi berperan dalam menunjang perubahan perilaku seseorang. Informasi yang diterima melalui media cetak, elektronik, pendidikan / penyuluhan, bukubuku dan sebagainya akan meningkatkan pengetahuan seseorang sehingga ia akan biasa memperbaiki atau merubah perilakunya menjadi lebih baik.
10) Perbedaan sikap ibu hamil trimester III sebelum dan setelah diberikan video penyuluhan persalinan

Adanya penyuluhan berbasis video whatsapp tentang persalinan ini sangat membantu dalam mengubah sikap yang negative menjadi positif. Menurut penelliti, faktor yang juga berpengaruh penting terhadap perubahan sikap yang positif ini adalah adanya pengetahuan responden yang sebagian besar sudah baik. Apabila pengetahuan baik maka sikap juga akan menjadi positif.

Menurut peneliti, pengetahuan yang baik pada ibu trimester III sangat berpengaruh terhadap perubahan sikap ibu trimester III dalam menghadapai persalinan untuk mengurangi angka kematian bayi dan proses persalinan yang aman. Pada penelitian ini, sikap responden sebelum dilakukan penyuluhan masih banyak yang negatif, namun mengalami peningkatan sikap yang positif setelah dilakukan penyuluhan, yang artinya memberikan informasi kepada ibu trimester III menjelang persalinan.

Keberhasilan penyuluhan tersebut tidak terlepas dari beberapa faktor yang melatarbelakanginya, seperti yang dikemukakan Notoatmodjo (2007) keberhasilan suatu penyuluhan kesehatan dapat dipengaruhi oleh beberapa faktor antara lain kesiapan penyuluh, sasaran dan proses penyuluhan. sikap dipengaruhi oleh faktorfaktor diantaranya adalah pengaruh orang lain yaitu komponen sosial yang ikut mempengaruhi sikap seseorang dan pengaruh lembaga pendidikan dan agama yang mempunyai pengaruh dalam pembentukan sikap dikarenakan keduanya meletakkan dasar pengertian konsep moral dalam diri individu.

\section{KESIMPULAN dan SARAN}

\section{Kesimpulan}

Berdasarkan hasil penelitian yang dilakukan, maka dapat diambil kesimpulan sebagai berikut:

1) Gambaran karakteristik umum ibu hamil trimester III di Puskesmas Klabang Kabupaten Bondowoso, menunjukkan bahwa Sebagian besar responden berusia 25 - 30 tahun sebanyak 15 orang $(45,5 \%)$, sebagian besar responden berpendidikan SMA sebanyak 11 orang(33,3\%), sebagian 
besar responden bekerja sebagai ibu rumah tangga sebanyak 14 orang $(42,4 \%)$, sebagian besar responden hamil yang kedua sebanyak 16 responden $(48,5 \%)$.

2) Pengetahuan ibu hamil trimester III sebelum diberikan penyuluhan berbasis video whatsapp tentang persalinan di wilayah kerja Puskesmas Klabang Kabupaten Bondowoso, sebagian besar dalam kategori cukup sebanyak 19 orang $(57,6 \%)$.

3) Pengetahuan ibu hamil trimester III setelah diberikan penyuluhan berbasis video whatsapp tentang persalinan di wilayah kerja Puskesmas Klabang Kabupaten Bondowoso, sebagian besar dalam kategori baik sebanyak 21orang $(63,6 \%)$.

4) Sikap ibu hamil trimester III sebelum diberikan penyuluhan berbasis video whatsapp tentang persalinan di wilayah kerja Puskesmas Klabang Kabupaten Bondowoso, sebagian besar dalam kategori sikap yang negatif sebanyak 28 orang $(84,8 \%)$.

5) Sikap ibu hamil trimester III setelah diberikan penyuluhan berbasis video whatsapp tentang persalinan di wilayah kerja Puskesmas Klabang Kabupaten Bondowoso, sebagian besar dalam kategori sikap yang positif sebanyak 24 orang $(72,7 \%)$.

6) Ada pengaruh tingkat pengetahuan ibu hamil trimester III sebelum dan setelah diberikan penyuluhan berbasis video whatsapp tentang persalinan di wilayah kerja Puskesmas Klabang Kabupaten Bondowoso, dengan $p$-value 0,000 .

7) Ada pengaruh sikap ibu hamil trimester III sebelum dan setelah diberikan penyuluhan berbasis video whatsapp tentang persalinan di wilayah kerja Puskesmas Klabang Kabupaten Bondowoso, dengan p-value 0,000 .

\section{Saran}

1) Penulis

Penulis memperoleh pengetahuan dan wawasan tentang pengaruh penyuluhan berbasis video whatsapp tentang persalinan terhadap pengetahuan dan sikap ibu trimester III di wilayah kerja Puskesmas Klabang Kabupaten Bondowoso., serta dapat digunakan untuk melaksanakan penelitian selanjutnya dengan hasil yang lebih baik.
2) Responden

Dijadikan bahan masukan bagi klien untuk terus menambah pengetahuan dan meningkatkan pengetahuan dan sikap ibu trimester III tentang persalinan yang aman dan tidak pergi ke dukun bayi pada saat melakukan persalinan.

3) Institusi Pendidikan

Dipakai sebagai bahan masukan bagi pendidikan dalam proses pembelajaran mahasiswa keperawatan, khususnya keperawatan maternitas, sehingga dapat diperoleh gambaran nyata tentang pengaruh penyuluhan berbasis video whatsapp tentang persalinan terhadap peningkatan pengetahuan dan dan sikap ibu trimester III menjelang persalinan yang aman dan nyaman.

4) Penelitian Lebih Lanjut

Dapat dilakukan penelitian lebih lanjut tentang pengaruh penyuluhan berbasis video whatsapp serta dengan menggunakan media pembanding, sehingga dapat menegtahui kefektifan media yang digunakan. Serta menggunakan penyuluhan pengaruh penyuluhan berbasis video whatsapp dalam melakukan penyuluhan di zaman perekembangan teknologi yang berkembang pesat seperti saat ini dengan tema penyuluhan yang lain.

\section{DAFTAR PUSTAKA}

Dinas Kesehatan Provinsi Jawa Timur, 2012, Pedoman Pemantauan Wilayah Setempat Kesehatan Ibu Dan Anak (PWS-KIA), Surabaya; 9.

Kementerian Kesehatan RI, Profil Kesehatan Indonesia 2012, Health Statistics, Jakarta, Kementerian Kesehatan RI; 2013

Al-Qur`an dan Terjemahannya. 2014. Jakarta: Pustaka al-Fatih

Dinas Kesehatan Provinsi Jawa Timur, 2016, Profil Kesehatan Provinsi Jawa Timur Tahun 2016, Surabaya, Dinas Kesehatan Provinsi Jawa Timur; 48.

Dinas Kesehatan Kabupaten Bondowoso, 2018, Evaluasi Capaian Program Kesehatan Ibu Kabupaten Bondowoso 
Semester III Tahun 2018; Bondowoso; 4.

Satiyu, Wawancara, Klabang, 28 Oktober 2018.

Nesi Novita, Yuneta Franciska, 2011, Promosi Kesehatan Dalam Pelayanan Kebidanan, Jakarta, Salemba Medika; 76. Ibid, diakses pada tanggal 12 Februari 2018 pukul 21:19

Kustandi, 2011. Media Pembelajaran Manual dan Digital. Bogor: Ghalia Indonesia.

Shak Abdulhak dan Deni Darmawan, Teknologi Pendidikan, (Bandung: PT Remaja Rosdakarya, 2015), hlm.110

Bennett, G. G., \& Glasgow, R. E. The delivery of public health interventions via the Internet: actualizing their potential. Annual review of public health. 2009;30

Bakri, Zakiyah, dkk. 2019. Faktor-Faktor Yang Berhubungan Dengan Pemilihan Metode KontrasepsiPada Wanita Usia Subur Di Wilayah Kerja Puskesmas Ranotana Weru. Jurnal Vol. 7 No. 1. Ilmu Keperawatan Fakultas Kedokteran: Universitas Sam Ratulangi

Budiman, A.R. 2013. Kapita Selekta Kuesioner Pengetahuan dan Sikap dalam Penelitian Kesehatan. Jakarta: Salemba Medika

Sudirman, D. (2016). Kontribusi dan Motivasi Pekerja Wanita dalam Meningkatkan Ekonomi Keluarga. Al-Ulum Ilmu Sosial Dan Humaniora, 1(2), 175-187

Goetzl, L.(2013). Kehamilan Diatas 35 Tahun Cetakan 1., Jakarta: Dian Rakyat.

Karmiti, dkk. 2018. Analisis Perbedaan Pengetahuan Ibu Hamil Terhadap Pemberian Penyuluhan Kesehatan Tentang Kehamilan Di Desa Tompo Wilayah Kerja Puskesmas Taopa Kabupaten Parigi Moutong. Skripsi.Fakultas Kesehatan
Masyarakat:

Universitas

Muhammadiyah Palu.

Kustandi, C, Sujipto, B. 2011. Media Pembelajaran Manual dan Digital. Bogor: Penerbit Ghalia Indonesia.

Andira, Vina Yuni. 2015. Pengaruh Penyuluhan Tentang P4K Terhadap Upaya Pencegahan Komplikasi Pada Ibu Hamil Di Desa Ngestihardjo Kasihan Bantul Tahun 2015.Naskah Publikasi. Sekolah Tinggi Ilmu Kesehatan: 'Aisyiyah Yogyakarta

Kholisotin (2017) 'Efektifitas paket edukasi preeklampsia terhadap pengetahuan, sikap, dan keterampilan ibu hamil yang beresiko mengalami preeklampsia di kabupaten situbondo', Jurnal Keperawatan, Universitas Muhammadiyah Jakarta.

Notoatmodjo, S., 2007, Promosi Kesehatan dan Ilmu Perilaku. Jakarta: PT. Rineka Cipta

Azwar, S. (2012).Penyusunan Skala Psikologi, Yogyakarta: Pustaka Pelajar 